dispel any lingering doubts that the existing anti money laundering requirements do not apply to dealings with possibly corrupt foreign officials.

The scale of fortunes acquired in recent cases like Abacha are so great there can be little scope for resisting the inference that they must have been acquired through some wrongdoing. A suspicious transaction is defined in the JMLSG Guidance Notes to be one, which is 'inconsistent with the customer's known legitimate business or personal activities'. The size of the transactions involved in such cases is so large that, absent an explanation, they were clearly inconsistent with the client's 'known legitimate business or personal activities' in which case the banks were (or at least ought to have been) suspicious. This means that all the elements of the offence under section 93A of the Criminal Justice Act 1988 (as amended) is present. It remains to be seen whether a disclosure report was made, giving the bank a defence to criminal liability. Of course, such a report would not provide a defence to civil liability.

The spate of recent money laundering scandals suggests intermediaries in this country have laundered the proceeds of foreign corruption. They have led to an impression that the law is deficient, which has perhaps prompted the preparation of the Guidelines. However, this impression is incorrect because, as I have mentioned, an offence would appear to have been committed. In any event, the Guidelines could not remedy any such deficiencies; quite apart from the uncertainty of the language used, the Guidelines are simply a voluntary code. Whilst the existing anti money laundering regime is not prefect, its objectives and effect are the same the Guidelines. The reason why these objectives and effects may not have been fulfilled is because of a failure to enforce the law. Both the Serious Fraud Office and the FSA have announced that they have initiated investigations into banks involved in handling funds on behalf of Abacha and this is something that the House of Commons International Development Committee is in the process of investigating. Hopefully this signals a determination to overcome past enforcement deficiencies.

Toby Graham

\title{
Free speech and the Human Rights Act 1998 by Paul Kearns
}

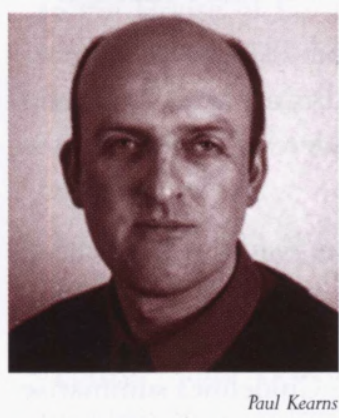

$\mathrm{T}$ The incorporation of most of the articles of the European Convention on Human Rights into English law by the Human Rights Act 1998 has involved the quasi-constitutional step of activating a rightsbased offensive for citizens against the foe of public authorities without the fully constitutional step of entrenchment. Freedom of expression, including symbolic as well as cognitive speech, is arguably the most primary of freedoms but it is not as highly prized under the European Convention as some suppose. In conflicts between free speech and religious lobbies, for example, free speech has often been compromised by the preferred protection of threatened religious precepts, and, in general, the legitimate interferences with free speech are relatively broad despite the fact that in constitutional terms, in many national jurisdictions, freedom of expression is one of the most widely accepted rights, on which other rights, such as that of freedom of assembly, are frequently parasitic.

As McGoldrick and O'Donnell have lucidly pointed out, free speech has a powerful normative status which ensures that it generally receives a purposive interpretation, and the rationales for that special status have been the search 
for truth, the right to individual self-fulfilment and the importance of everyone's full communicative participation in a democracy. In free speech litigation, one first has to identify the specific category of free speech involved, and then analyse it in terms of the wealth of rationales for freedom of speech, including, notably, its limitation. The complex case law result emerges, ideally, from a very careful balancing of various rights, interests and values that impact on the free speech terrain concerned.

Article 10 of the European Convention on Human Rights, from which the free speech provision in the Human Rights Act 1998 is drawn, provides:

(1) Everyone has the right to freedom of expression. This right shall include freedom to hold opinions and to receive and impart information and ideas without interference by public authority and regardless of frontiers. This Article shall not prevent states from requiring the licensing of broadcasting, television or cinema enterprises.

(2) The exercise of these freedoms, since it carries with it duties and responsibilities, may be subject to such formalities, conditions, restrictions or penalties as are prescribed by law and are necessary in a democratic society, in the interests of national security, territorial integrity or public safety, for the prevention of disorder and crime, for the protection of health or morals, for the protection of the reputation or rights of others, for preventing the disclosure of information received in confidence, or for maintaining the authority and impartiality of the judiciary.'

With the assistance of an excellent overview by Wadham and Mountfield, the following general observations can be made: The free speech right contained in Article 10 concerns the freedom to hold ideas, and to receive options and information, as well as the right to express them, and the concept 'expression' covers words, pictures, images and actions intended to express an idea or to present information. A personal opinion is that the non-cognitive as a category, such as represented by abstract art, is also covered, so expression may be a more accurate term in this context than speech. Article 10 does not create a general right to freedom of information but, a little paradoxically, it can assist someone who is prevented from receiving information. In the United Kingdom, the recently en-acted Freedom of Information Act 2000 goes some way to creating a right to information but only in certain strictly-circumscribed circumstances.

A wide range of types of expression is protected by Article 10 including political speech, which is the type given highest priority by the European Convention on Human Rights in practice (Bowman $v$ United Kingdom (1998) 26 EHRR 1). Also covered are journalistic speech, artistic 'speech' and commercial speech, the relevant case law being, respectively, Goodwin v United Kingdom (1996) 22 EHRR 123, Muller v Switzerland (1988) 13 EHRR 212 and Colman $v$ United Kingdom (1993) 18 EHRR 119. The
European Court of Human Rights has rather disingenuously disavowed a theoretical basis for such distinctions between types of speech. Another doctrinal problem for the Court has been the correct balance to be achieved between the importance of the right to freedom of expression and the rights and freedoms of others. This is unsurprising because the right of freedom of expression can often jeopardise competing social interests such as the respect for thought, conscience and religion, the privacy of others, the protection of the democratic process and the right to a fair trial. However, it is reassuringly clear from the case law that the Court requires strong justification for interfering with the right to free speech, which is a matter of some detail to be considered later in this article.

The juridicial zone of free speech issues encompasses areas of official secrecy, privacy and obscenity, and it is these three subjects that form the basis of the ensuing discussion, though mention will be made of other issues for the sake of universality of comprehension for the reader.

In Article 10(2) of the European Convention on Human Rights the various legitimate reasons for restricting free speech are set out. In terms of official secrecy, first, the relevant controls include those which are in the interests of national security. Like the English courts, the European Court of Human Rights has not given a clear indication of what exactly comprises 'national security'. The infamous Spycatcher cases demonstrate, though, that the issue is definitely justifiable. In The Observer and Guardian v United Kingdom (1991) 14 EHRR 153, the European Court of Human Rights held that an interference intended to maintain the authority of judges pending trial, and to preserve national security, pursued legitimate objectives. It was deemed by the Court necessary in a democratic society to interfere by way of injunction to conserve national security confidentiality. However, once the salient information was no longer confidential, the objective of preserving confidence in the security services had already been realised by initiating proceedings, and was insufficient to interfere with the right protected by Article 10.

Information that affects criminal investigations constitutes secret information and a limitation on publication can accordingly be justified on the basis of the secrecy objective. Article 10(2) also covers the prevention of disclosure of matter received in confidence, which can, of course, be used where relevant to embrace government information. Article 10 applies to members of the security services and the civil service and it is not yet clear how Article 10 will apply to 'whistleblowers' who seek to reveal information under the Official Secrets Act 1989 on the foundation of 'public interest'. At the moment, in England, there is no watertight defence available in such instances. Commentator Rambert de Mello has noted that, in cases pertaining to national security, the domestic 
court is not usually inclined to examine the subject matter before the public authority concerned to ascertain whether its decision was correct. This may change under the Human Rights Act 1998 in the shape of an expectation of investigation by the court. In the area of official secrecy, then, the law is somewhat, as yet, inchoate.

On the topic of secrecy, one of the fundamental requirements for freedom of the press is the protection of journalists' sources. An order for the disclosure of any source is prima facie incompatible with Article 10 unless it can be convincingly justified under the Article 10(2) derogations.

Article 8 of the European Convention on Human Rights provides:

'(1) Everyone has the right to respect for his private and family life, his home and his correspondence'

(2) There shall be no interference by a public authority with the exercise of this right except such as in accordance with the law and is necessary in a democratic society in the interests of national security, public safety or the economic well-being of the country, for the prevention of disorder or crime, for the protection of health or morals, or for the protection of health or morals, or for the protection of rights and freedoms of others.'

How this privacy right will affect institutions like the media is a matter for debate. Since the right can only apply against public authorities, the BBC is arguably the only feasible media body to be directly affected according to media law specialist Peter Carey. Nevertheless, a not untenable view is that domestic courts come within the 'public authority' nomenclature and that the domestic judiciary has a consequent obligation to develop the common law in England to ensure more extensive compliance with the European Convention rights including the privacy provision. However, a person claiming infringement of his privacy right under Article 8 must show that his private or family life has been disrespected by a media body and such disrespect may be difficult to prove in the absence of sufficiently intrusive media action as has already been deemed to contravene the privacy right in already existing European Court of Human Rights cases.

The interaction of the right to free speech and the right to privacy is very interesting virgin territory under the Human Rights Act 1998. Although the Act specifies that 'particular regard' must be had to freedom of expression where that right is affected by an action, it is not an absolute right, and a notoriously conservative judiciary in England may well create a privacy right of greater strength than most commentators expect, not least given the Article 10 (2) attention paid to the rights and reputations of others. Respecting the legislation, though, the balance is clearly tilted in favour of free speech by courtesy of section 12 of the 1998 Act. This provides that where a court is considering whether to grant any relief, which, if granted, might affect the exercise of the Convention right to freedom of expression, it must:

'Have particular regard to the importance of the Convention right to freedom of expression and, where the proceedings relate to material which the respondent claims, or which appears to the court, to be journalistic, literary or artistic material (or conduct connected with such material), to -

(a) the extent to which -

(i) the material has, or is about to, become available to the public; or

(ii) it is, or would be, in the public interest for the material to be published;

(b) any relevant privacy code.'

No such relief is to be granted in the absence of the respondent unless the court is satisfied that the applicant has taken all practical steps to notify them and/or it is satisfied that there are compelling reasons why they should not be notified. There is no prior restraint of any publication before trial unless the court is likely to establish that publication should not be allowed. Steven Greer is of the opinion that s.12 is a welcome provision even though it could have been more clearly drafted. Its merit lies in the fact that it is the only part of the 1998 Act that seeks to clarify the relationship between two Convention rights in such a specific and detailed manner. That scheme ensures that all the appropriate facts are properly considered in any given dispute.

Article 10 of the European Convention on Human Rights is also very relevant to matters of obscenity and indecency. Here there is a derogation the state can utilise on the basis of 'protection of health or morals' and such restrictions have been deemed permissible by the Strasbourg institutions as legitimate limitations on free speech in this sensitive area. According to Richard Stone, the European Court of Human Rights' decisions may not be very helpful because in this field of allegedly immoral publications the Court has granted a notably extensive 'margin of appreciation' to domestic jurisdictions. This concept is one of subsidiarity whereby a state is allowed a degree of latitude in its application of the relevant law without interference by a supra-national European human rights standard. To come within this allowable ambit the state control must be 'prescribed by law', promote a 'legitimate aim' and be 'necessary in a democratic society' for the achievement of the specific objective of the measure. In Handyside $v$ United Kingdom (1976) 1 EHRR 737, the Court used the 'margin of appreciation' device to extend appropriate discretion to the contracting state in the following way:

'The Contracting States have each fashioned their approach in the light of the situation obtaining in their respective territories; they have had regard, inter alia, to the different views prevailing there about the demands of the protection of morals in a 
democratic society. The fact that most of them decided to allow the work (under consideration) to be distributed does not mean that (any) contrary decision was a breach of Article 10.'

Controversially, in Wingrove v United Kingdom (1997) 24 EHRR 1, state discretion was also permitted regarding the English censorship mechanism regulating videos and films. Nigel Wingrove made a short video called Visions of Ecstasy in which he depicted the ecstatic visions of Saint Teresa of Avila in an erotic way. The British Board of Film Classification (BBFC) having refused the film a certificate, Wingrove ultimately appealed to the Strasbourg institutions. The European Court of Human Rights upheld the national decisions as not involving a breach of Article 10 because, although the application of blasphemy laws was deemed rare, and prior restraint called for particular scrutiny, the concern of the English BBFC that the public distribution of the video might 'outrage and insult the feelings of believing Christians' meant that the censorship could not be said to be an 'arbitrary or excessive' measure. This is a most unsatisfactory result for advocates of free speech, involving the abdication of judicial responsibility for imposing a morality in line with more liberal European mores.

Despite Wingrove, Janis, Kay and Bradley, authorities on European human rights law, claim that from the standpoint of bringing national law in conformity with Convention rights, the Human Rights Act 1998 goes a long way; but much depends on the response of the national judiciary. A little-observed matter not specifically addressed by the Act is the degree to which the domestic courts may re-state common law rules where these are inconsistent with the Convention. This is probably going to be less revolutionary than some liberals expect but the Act at least resolves the principal problems caused by the application of a treaty unincorporated in domestic law and aspires to have profound constitutional significance as a liberalising measure that judges are at least at liberty to galvanise in forthcoming case law.

There are several possibilities as to how the concept of the 'margin of appreciation' will mutate in domestic law within the specific context of Article 10. Since free speech encompasses both artistic and cultural expression it is feasible that it will be held necessary in a democratic society to protect objects of religion from unwarranted aggression. This is certainly in line with the European Court of Human Rights' prevailing policy of promoting freedom of religion as a specifically valued ideal. One can also envisage that when a public authority seeks to gag the press, its power to restrict free speech may be interpreted narrowly since one significant role of the press is to impart valuable information and even information that is arguably 'hate speech'. If the public is not explicitly concerned about business confidentiality between various interested parties, it may be that in such circumstances restriction of publication of such matter will constitute justifiable interference with the freedom under Article 10. However, the derogations in Article 10(2) must be interpreted narrowly or restrictively under European human rights law governed by Strasbourg. This has a particular significance for moral issues, an area where restraints on national oppression are theoretically and actually provided. If free speech is used too abusively, so as to in effect deny the abused of one of his or her other rights, restraint of the speech is conceivable, even if only a proposition deriving from the dissenting opinion of judges Palm, Pekkanen and Makarczyk in Otto-Preminger Institut v Austria (1994) 19 EHRR 34 at paras. 7 and 8.

As a matter of practice, actions taken by a public authority will not be held to be contrary to the European Convention on Human Rights on the basis that they are not the optimal measures in the view of a court, provided that the actions come within a relatively small array of permissible alternatives. These comprise the exercise of a degree of latitude on the question of Article 10(2) restrictions, as previously witnessed supra; a course of conduct in executing its duties under statute that does not infringe Convention rights; a fresh evaluation of facts presented to the decisionmaker, and the choice of measures it deems appropriate in accordance with European Convention exemplars. A domestic court is obligated to consider all relevant arguments including, crucially, whether the reasons given by the public authority for its decision are relevant and sufficient under Article 10(2).

At present, the Human Rights Act 1998 cannot be equated with a Bill of Rights and, in the absence of entrenchment, will have to be assessed in this context only after a number of years of operation. It is difficult to hypothesise about its eventual constitutional status given its short period in force to date. Nevertheless, a major factor in the profundity of its impression on English law rests with the judiciary, which may be conservative, activist or dynamic in its corporate application of the Act's potentially far-reaching content. There may be common law upheaval of a magnitude that requires a reappraisal of the Act's practical constitutional position in relation to sovereignty and written constitutionality. In the specific context of free speech, which was merely a rather inert residual liberty in England rather than an invokable right of citizens prior to the Act, it can be said that the legislation refreshes and modernises our heavily traditional constitutional framework in favour of more scope for original debate and artistic and other creativity. This is a requirement not only of the globalised post-modernism that surrounds our law but also of the European Union to which our commitment in terms of constitutional methods is unlikely to remain dormant for much longer.

\section{Dr Paul Kearns}

Lecturer in Law, University of Manchester 